(c) American Dairy Science Association, 2006.

\title{
Omitting the Dry-Off Period Negatively Affects Colostrum and Milk Yield in Dairy Goats
}

\author{
G. Caja, ${ }^{* 1}$ A. A. K. Salama, ${ }^{\star} \dagger$ and X. Such ${ }^{\star}$ \\ *Grup de Recerca en Remugants, Departament de Ciència Animal i dels Aliments, Universitat Autónoma de Barcelona, \\ 08193 Bellaterra, Spain \\ †Sheep and Goat Research Department, Animal Production Research Institute, 4 Nadi El-Said St., 12311 Dokki, Giza, Egypt
}

\section{ABSTRACT}

Seventeen pregnant multiparous Murciano-Granadina dairy goats, kept in a semi-intensive exploitation system with once daily milking throughout lactation and 1 kidding per year (milk yield, $577 \mathrm{~L} / 300 \mathrm{~d}$ ), were used to study the effects of dry-off period length on performance during the subsequent lactation. Goats were mated at wk 29 of lactation and were assigned to 2 experimental groups according to dry-off treatment: goats that were dried off $56 \mathrm{~d}$ before expected kidding $(\mathrm{D} 56 ; \mathrm{n}=9)$ and goats without dry-off (D0; $\mathrm{n}=8)$. After parturition, kids were removed from their mothers and weighed before suckling. Goats were hand milked to obtain colostrum and were machine milked thereafter. Colostrum was sampled for composition and IgG analysis. Milk yield was recorded weekly during the preceding and subsequent lactations. Udders were biopsied in a sample of goats at $d-65$ (late lactation), $d-49$ (during dry-off), and d 48 (early lactation) to kidding (d 0). Apoptotic and proliferating cells in mammary tissues were detected immunohistochemically. Five goats $(63 \%)$ in the D0 group dried off spontaneously at $27 \pm 4 \mathrm{~d}$ before kidding and were considered separately (D27). The rest of the D0 goats yielded $0.86 \mathrm{~L} / \mathrm{d}$ from $\mathrm{d}-56$ to kidding. Goats kidded 2.25 kids/goat, but the D0 kids had smaller birth weights $(1.7 \mathrm{~kg})$ than the D27 $(2.2 \mathrm{~kg})$ and D56 $(2.1 \mathrm{~kg})$ kids. Colostrum of the D0 goats contained less IgG $(5.6 \mathrm{mg} / \mathrm{mL})$ than the D27 $(32.9 \mathrm{mg} / \mathrm{mL})$ and the D56 $(42.4 \mathrm{mg} / \mathrm{mL})$ goats. In the subsequent lactation $(210 \mathrm{~d})$, the $\mathrm{D} 0$ goats produced less milk $(1.78 \mathrm{~L} / \mathrm{d})$ than the D27 $(2.51 \mathrm{~L} / \mathrm{d})$ and D56 $(2.24 \mathrm{~L} / \mathrm{d})$ goats, with no detectable difference between the D27 and D56 goats. Apoptosis and proliferation indices increased from 0.51 and $2.09 \%$, at $d-65$, to 1.75 and $7.12 \%$ at $d-49$ (d 7 of dry-off) in D56 goats. Despite differences in daily milk yield during early lactation (d 48 ) between the D0, D27, and D56 treatments (1.73, 2.68 , and $2.53 \mathrm{~L} / \mathrm{d}$, respectively), no differences in

Received March 1, 2006.

Accepted June 22, 2006.

${ }^{1}$ Corresponding author: gerardo.caja@uab.es apoptosis or proliferation indices were detected (D0: 0.65 and 2.48\%; D27: 0.68 and 1.37\%; and D56: 0.71 and $2.95 \%$ ), indicating that duration of the dry period did not affect mammary cell turnover during the subsequent lactation. Omitting the dry period between lactations reduced the quality of colostrum and had negative effects on milk yield in dairy goats. Goats dried off spontaneously for $27 \mathrm{~d}$ were as productive as goats dried off for $56 \mathrm{~d}$, indicating that less than 2 mo of dry-off may be sufficient in practice.

Key words: continuous milking, apoptosis, lactogenesis, dairy goat

\section{INTRODUCTION}

A nonlactating period before parturition is believed to be necessary to permit replacement of damaged or senescent epithelial cells (Capuco et al., 1997) and hence to maximize milk production during the ensuing lactation. Omitting the dry period in dairy cows reduced milk yield by 15 to $25 \%$ during the subsequent lactation (Swanson, 1965; Remond et al., 1992), indicating that a dry period between lactations is indispensable for dairy cows. Available information indicates that the dry period seems to be unnecessary in dairy goats. The only study carried out in multiparous goats used the half-udder design (Fowler et al., 1991) and showed that continuously milked half-udders were as productive as half-udders not milked (given a dry period).

Acquisition of passive immunity by the neonate depends on consumption of a sufficient amount of colostral IgG before cessation of macromolecular transport by the intestine (Stott and Fellah, 1983). Continuous milking of 1 half-udder throughout the dry period in dairy cows reduced the massive selective transfer of blood IgG into the colostrum of these glands (Brandon and Lascelles, 1975). In contrast, colostrum formation was normal in the contralateral, nonmilked glands. These results indicate that local regulation of colostrum formation exists and that local signals, such as continuous milking throughout the dry period, can impede colostrogenesis, even during late gestation when hormonal influences favor its establishment. If colostrum contains 
a small concentration of $\mathrm{IgG}$, the neonate should be fed a large amount of colostrum to obtain a sufficient amount of IgG. However, Stott and Fellah (1983) suggested that large amounts of colostrum containing a small concentration of IgG would not be absorbed adequately; rather, limited amounts of colostrum having a large concentration of IgG may be more beneficial. The effect of omitting the dry period on colostrum quality has not been studied in dairy goats.

Milk yield depends on the activity and number of mammary epithelial cells (Knight, 2000). The number of mammary cells is determined by the rates of cell apoptosis and proliferation. Apoptosis and proliferation occur in the mammary gland throughout lactation, resulting in a considerable turnover of mammary cells (Capuco et al., 2001). Capuco et al. (2001) reported daily rates of proliferation and apoptosis in the bovine mammary gland of 0.3 and $0.56 \%$, respectively. Assuming that these indices are constant throughout lactation and that the cells that die are not those that have proliferated, they calculated that $90 \%$ of mammary cells are renewed during lactation. Moreover, they estimated that if mammary cells die after proliferation, then more than half of the cells could renew themselves during a 240-d lactation. Besides stage of lactation, some management factors such as bST injection (Capuco et al., 2001), milking frequency (Hale et al., 2003), and diet energy density (Norgaard et al., 2005) affect the indices of mammary apoptosis and proliferation. It is not known whether omitting the dry period can affect mammary cell turnover in the subsequent lactation.

The objective of this study was to investigate the effects of omitting the dry period on colostrum quality, milk yield, and mammary cell turnover during the subsequent lactation in Murciano-Granadina goats.

\section{MATERIALS AND METHODS}

The experimental procedures and animal care conditions were approved by the Ethical Committee of Animal and Human Experimentation of the Universitat Autonoma de Barcelona (reference CEEAH 400/2002).

\section{Animals and Management Conditions}

Seventeen pregnant multiparous Murciano-Granadina dairy goats in the herd of the S1GCE (Servei de Granges i Camps Experimentals) of the Universitat Autonoma de Barcelona were used. Goats were mated naturally at wk 29 of lactation (April) after buck-induced estrus. Eight weeks before the expected kidding date (293 $\pm 0.6 \mathrm{DIM})$, goats were assigned to 2 experimental dry periods of either $56 \mathrm{~d}(\mathbf{D 5 6} ; \mathrm{n}=9)$ or $0 \mathrm{~d}$ $($ D0; $\mathrm{n}=8)$. Five of the 8 goats assigned to the D0 group reduced milk yield dramatically during pregnancy and dried off spontaneously at $27 \pm 4 \mathrm{~d}$ before kidding, and were thereafter considered as a separate group (D27). Mean values for age $(4.0 \pm 0.5,4.0 \pm 0.6$, and $3.7 \pm 0.7$ yr) and parity $(2.8 \pm 0.4,3.0 \pm 0.6$, and $2.7 \pm 0.7)$ were similar for D56, D27, and D0 goats, respectively. Goats grazed for $6 \mathrm{~h}$ daily and the diets were supplemented indoors with a commercial concentrate (6.4 MJ of $\mathrm{NE}_{\mathrm{L}} /$ $\mathrm{kg}$ and $160 \mathrm{~g}$ of $\mathrm{CP} / \mathrm{kg}$; as fed) at a flat rate of 0.5 to $1.0 \mathrm{~kg} / \mathrm{d}$ according to the stage of lactation, plus $0.5 \mathrm{~kg}$ of dehydrated alfalfa hay and $0.5 \mathrm{~kg}$ of alfalfa pellets. During the dry period, goats were maintained in pens and fed a dehydrated mixture of $50 \%$ whole-plant maize, $50 \%$ alfalfa ad libitum, and $0.3 \mathrm{~kg} / \mathrm{d}$ of concentrate. Moreover, lactating goats received $0.5 \mathrm{~kg} / \mathrm{d}$ of concentrate in the milking parlor.

Goats were milked in a double-12 parallel milking parlor (Westfalia-Separator Ibérica, Granollers, Spain) equipped with milk-recording jars ( $2 \mathrm{~L} \pm 5 \%)$, and a low milk pipeline. The milking machine was set at a vacuum pressure of $42 \mathrm{kPa}$, a pulsation rate of 90 pulses/min, and a pulsation ratio of $66 \%$. The milking routine included machine milking, stripping before cluster removal, and teat dipping in an iodine solution (P3-cide plus; Henkel Hygiene, Barcelona, Spain).

\section{Sample Collection, Analyses, and Measurements}

Milk yield was recorded weekly by using the recording jars in the milking parlor until wk 30 of the subsequent lactation (wk 80 of the experiment). After parturition, kids were weighed and separated from their mothers before suckling. Goats were hand milked, and fresh colostrum samples were collected to determine specific gravity (SG) and colostral composition. For IgG concentration, colostral samples were frozen at $-20^{\circ} \mathrm{C}$ until analysis. The SG of colostrum was measured using a density flask (Afora, Madrid, Spain) according to Lewis (1987). Colostrum total solids were calculated after drying in an oven at $103^{\circ} \mathrm{C}$ overnight. Fat was analyzed by the Gerber method. Noncasein protein was measured by Kjeldahl analysis of the filtrate after precipitation with $10 \%$ acetic acid and $1 \mathrm{M}$ sodium acetate, and NPN was measured by Kjeldahl analysis of the filtrate after precipitation with $20 \% \mathrm{TCA}$ (International Dairy Federation, 1993). Total protein was expressed as $\mathrm{N} \times 6.38$, and $\mathrm{CN}$ was calculated as the difference between total protein and non-CN protein.

The concentration of IgG in the colostrum was determined by the radial immunodiffusion technique using VET-RID kit plates specific for goat IgG (Bethyl Laboratories, Montgomery, TX). Colostrum samples were diluted (1:10) using PBS ( $\mathrm{pH}=7.4$ ), and plate wells were then filled with $5 \mu \mathrm{L}$ of diluted colostrum. Plates were 
incubated at room temperature for $24 \mathrm{~h}$, after which diameters of the ring-shaped precipitates were measured to the nearest tenth of a millimeter using a scaled ocular of a microscope (Olympus SZH; Olympus Corporation, Tokyo, Japan). A reference curve was constructed by plotting the diameter of the precipitated rings of 3 standard IgG concentrations $(250,1,000$, and $2,000 \mathrm{mg} / \mathrm{dL}$ ) on 2-cycle semilogarithmic graph paper. The concentration of IgG in the samples was determined by interpolation from the reference curve.

\section{Mammary Biopsies and Immunohistochemistry}

Seven goats having similar BW $(48.3 \pm 1.3 \mathrm{~kg})$ and milk yields $(0.54 \pm 0.19 \mathrm{~L} / \mathrm{d})$ at the end of the preceding lactation were chosen for udder biopsy. Mammary biopsies of milked udders were collected after s.c. local anesthesia ( $2 \mathrm{~mL}$ of lidocaine 2\%; B. Braun Medical, Barcelona, Spain) and skin incision with a scalpel in a half udder by using a 14-gauge needle (Bard Max ·Core, Covington, GA). The biopsy needle was introduced approximately $3 \mathrm{~cm}$ into the parenchyma 2 or 3 times to obtain sufficient tissue.

The first biopsy was obtained from 7 goats (3 D56 and $4 \mathrm{D} 0)$ at $d 284 \pm 1.6$ of the lactation preceding the dry-period treatment. The second biopsy was programmed $7 \mathrm{~d}$ after initiating the dry period to compare lactation and involution in the same D56 goats. No biopsies were planned in the D0 goats because no significant udder changes were expected after $1 \mathrm{wk}$ of lactation. Nevertheless, 3 of the 4 biopsied D0 goats did not maintain lactation and spontaneously dried off, becoming the D27 nonlactating group. The last biopsy was obtained at $d 48 \pm 1.1$ of the lactation subsequent to the dry-period treatment from 9 goats ( 3 goats in D56 biopsied twice previously, 3 goats in D27 biopsied once previously, 1 goat in D0 biopsied once previously, and 2 goats in D0 biopsied for the first time).

Mammary samples were fixed in $10 \%$ neutral-buffered formalin overnight at $4^{\circ} \mathrm{C}$ before being transferred to $70 \%$ ethanol until further processing. Samples were embedded in paraffin, cut at $3 \mu \mathrm{m}$, and stained with hematoxylin-eosin, or were processed for detection of cell proliferation by localizing proliferating cell nuclear antigen (PCNA) and cell apoptosis using terminal deoxynucleotidyl transferase dUTP nick-end labeling (TUNEL).

PCNA Localization. Deparaffinized rehydrated tissue slides were incubated in $3 \% \mathrm{H}_{2} \mathrm{O}_{2}$ for $30 \mathrm{~min}$ to inhibit endogenous peroxidase. To unmask the antigens, tissue slides were placed in a covered glass staining dish containing $10 \mathrm{mM}$ citrate buffer ( $\mathrm{pH} \mathrm{6.0)}$ and were microwave-heated for $10 \mathrm{~min}$. The slides were then incubated with bovine albumin in PBS (60 min) to block nonspecific binding of antibodies. To stain PCNA, slides were then incubated with $100 \mu \mathrm{L}$ of diluted mouse monoclonal antibody to PCNA (clone PC10, BioGenex, San Ramon, CA) overnight at $4^{\circ} \mathrm{C}$. The next morning, slides were incubated for $60 \mathrm{~min}$ at room temperature with 1:200 goat antimouse Ig biotin (DakoCytomation, Glostrup, Denmark) as a secondary antibody. Slides were then incubated with 1:100 avidin-biotin peroxidase complex (Immuno Pure ABC Peroxidase Staining Kit Standard; Pierce Biotechnology, Rockford, IL) for another $60 \mathrm{~min}$ at room temperature. Slides were incubated for 5 to $10 \mathrm{~min}$ with the chromagen, 3,3'diaminobenzidine tetrahydrochloride (Sigma, Madrid, Spain) in PBS containing $0.04 \%$ hydrogen peroxide. Finally, slides were counterstained with hematoxylin.

Detection of Cell Death by TUNEL. A commercial kit (Apop Tag; Serologicals Corporation, Norcross, GA) was used to visualize apoptotic cells. After deparaffinization and rehydration, slides were incubated with proteinase $\mathrm{K}(20 \mu \mathrm{g} / \mathrm{mL}$ of PBS). Slides were quenched with $2 \% \mathrm{H}_{2} \mathrm{O}_{2}$ in PBS for 5 min, incubated in equilibration buffer for $20 \mathrm{~min}$, and then incubated with terminal deoxynucleotidyl transferase for $60 \mathrm{~min}$ in a humidified chamber at $37^{\circ} \mathrm{C}$. Slides were washed with stop-wash buffer for $20 \mathrm{~min}$ at room temperature and then incubated with antidigoxigenin-peroxidase for $30 \mathrm{~min}$ at room temperature in a humidified chamber. Tissue sections were incubated for 5 to 10 min with 3,3'-diaminobenzidine tetrahydrochloride (Sigma) in PBS containing $0.04 \%$ hydrogen peroxide. Sections were washed with distilled water and then counterstained with hematoxylin.

Cell Counting. Tissue sections were viewed by light microscopy (Olympus BH2; Olympus Corporation) to quantify PCNA antigen-expressing cells and apoptotic cells. For each tissue section, 5 microscopic fields were quantified. A field was selected under low power and slightly out of focus; the objective was then switched to greater power, a digital image of the microscope field was taken at 100× magnification, and cells were counted on a computer monitor. Photographs of mammary tissue were used to count the numbers of cells per alveolus.

\section{Statistical Analyses}

Data were analyzed by using a mixed-models procedure for repeated measurements (PROC MIXED; SAS 8.2; SAS Inst. Inc., Cary, NC). The mixed model contained the random effect of animal within the dry-period duration (treatment); fixed effects of treatment and week of lactation; the interaction between treatment and week of lactation; and residual error. Milk yield during $300 \mathrm{~d}$ of the previous lactation was used as a 
Table 1. Effect of dry-period duration on the birth weight of kids, and specific gravity and composition of colostrum in dairy goats

\begin{tabular}{lccc}
\hline & \multicolumn{3}{c}{ Dry-period duration ${ }^{1}$} \\
\cline { 2 - 4 } Item & $\mathrm{D} 56(\mathrm{n}=9)$ & $\mathrm{D} 27(\mathrm{n}=5)$ & $\mathrm{D} 0(\mathrm{n}=3)$ \\
\hline Kidding rate, kids/goat & $2.46^{\mathrm{a}} \pm 0.18$ & $1.80^{\mathrm{b}} \pm 0.23$ & $2.33^{\mathrm{ab}} \pm 0.29$ \\
Kid birth weight, kg & $2.14^{\mathrm{a}} \pm 0.10$ & $2.25^{\mathrm{a}} \pm 0.14$ & $1.73^{\mathrm{b}} \pm 0.16$ \\
Colostrum & & & \\
Specific gravity & $1.053^{\mathrm{a}} \pm 0.002$ & $1.048^{\mathrm{a}} \pm 0.003$ & $1.032^{\mathrm{b}} \pm 0.004$ \\
Log IgG, mg/mL & $1.61^{\mathrm{a}} \pm 0.04$ & $1.51^{\mathrm{a}} \pm 0.06$ & $0.74^{\mathrm{b}} \pm 0.07$ \\
Total solids, \% & $23.0^{\mathrm{a}} \pm 1.0$ & $20.1^{\mathrm{ab}} \pm 1.5$ & $15.7^{\mathrm{b}} \pm 1.9$ \\
Fat, \% & $6.37 \pm 0.39$ & $5.78 \pm 0.61$ & $6.28 \pm 0.78$ \\
Protein, \% & $13.19^{\mathrm{a}} \pm 0.75$ & $10.52^{\mathrm{a}} \pm 1.15$ & $4.34^{\mathrm{b}} \pm 1.49$ \\
CN, \% & $3.64 \pm 0.20$ & $2.92 \pm 0.31$ & $2.77 \pm 0.39$ \\
CN, \% of protein & $28.2^{\mathrm{b}} \pm 1.9$ & $28.1^{\mathrm{b}} \pm 2.9$ & $63.1^{\mathrm{a}} \pm 3.8$ \\
Whey protein, \% & $9.05^{\mathrm{a}} \pm 0.66$ & $7.18^{\mathrm{a}} \pm 1.02$ & $1.28^{\mathrm{b}} \pm 1.31$ \\
NPN, \% & $0.51^{\mathrm{a}} \pm 0.02$ & $0.42^{\mathrm{b}} \pm 0.04$ & $0.29^{\mathrm{c}} \pm 0.04$ \\
\hline
\end{tabular}

${ }^{\mathrm{a}-\mathrm{c}}$ Means within a row having different superscript letters differ $(P<0.05)$

${ }^{1}$ Dried off for $56 \mathrm{~d}$ (D56), dried off spontaneously for $27 \mathrm{~d}$ (D27), or without dry-off (D0).

covariate. Milk persistency, colostral composition, and mammary tissue traits were analyzed by using oneway ANOVA (PROC GLM; SAS 8.2; SAS Inst. Inc.) with a model containing the effect of treatment and residual error. Data were tested for the normality of distribution, and a logarithmic transformation $\left(\log _{10}\right)$ was applied to IgG concentrations. Pearson correlation coefficients between colostral components also were calculated.

\section{RESULTS AND DISCUSSION}

According to the experimental treatments, D56 goats were dried off intentionally even though they were still lactating. For unknown reasons, of the 8 goats assigned to the D0 treatment, only 3 goats (37\%) had continuous secretory activity and were able to maintain lactation until kidding. Milk yield in the remaining 5 goats decreased dramatically, and goats spontaneously dried off 4 wk before kidding (D27). Annen et al. (2004) also described spontaneous drying off in dairy cows submitted to continuous milking during advanced pregnancy. Under the management conditions of our experiment, goats were milked once daily and kept in pens during late lactation and advanced pregnancy (summer). With greater daily milking frequency and earlier postpartum mating, more goats might have continued lactating without spontaneously drying off. Actual durations of the dry-off periods were $56 \pm 1$ and $27 \pm 4 \mathrm{~d}$ for the D56 and $\mathrm{D} 27$ goats, respectively. The kidding period for this study was $8 \mathrm{~d}$ long.

\section{Birth Weight of Kids and Colostral Quality}

The D56 and D0 goats had similar kidding rates $(2.40$ $\mathrm{kid} /$ goat $)$, but the D27 group had fewer $(P<0.05)$ kids than the D56 goats (Table 1). Kids of the D0 goats had smaller $(P<0.05)$ birth weights than kids from the D56 and D27 goats (Table 1). Decreased birth weights of the D0 kids may be a consequence of nutritive stress resulting from the competition between lactation and pregnancy, especially during the last third of gestation when fetal growth is the greatest. Previously, prepartum energy or protein restriction was shown to reduce birth weight by 6 to $10 \%$ in goats (Sahlu et al., 1995). Nevertheless, reducing or eliminating the dry period in dairy cows did not affect calf birth weight (Grummer and Rastani, 2004). The SG of D0 colostrum was smaller $(P<0.01)$ than those from D56 and D27 colostrum, indicating a poorer quality of colostrum from goats milked throughout pregnancy (Table 1). No values for the SG of colostrum from goats are available to compare with our results. The SG of D0 colostrum (1.032) was slightly greater than values for normal goat milk, which ranged from 1.022 to 1.026 (Guo et al., 2001). Measurement of the colostral SG provides an inexpensive and practical method of estimating the colostral Ig concentration in cows (Fleenor and Stott, 1980). Because kids of D0 goats had smaller birth weights and their mothers produced colostrum having a reduced SG, colostrum from the D27 and D56 goats was used to feed the D0 kids.

Colostrum from the D0 goats contained smaller $(P<$ $0.01)$ concentrations of IgG $(5.6 \mathrm{mg} / \mathrm{mL})$ than that from the D56 $(42.4 \mathrm{mg} / \mathrm{mL})$ and $\mathrm{D} 27(32.9 \mathrm{mg} / \mathrm{mL})$ goats. Continuous milking adversely affected colostrogenesis and resulted in the colostrum from D0 goats having a reduced concentration of IgG in our experiment. As parturition approaches, massive selective transfer of blood IgG into the colostrum in the dry mammary gland increases the concentration of IgG in the colostrum (Brandon and Lascelles, 1975). This selective transfer of IgG is locally controlled by mammary epithelial cells, 
Table 2. Correlation coefficients of colostral IgG, protein fractions, fat, total solids, and colostral specific gravity in dairy goats dried off for 56 or $27 \mathrm{~d}$ before kidding $(\mathrm{n}=14)$

\begin{tabular}{lllllllll}
\hline Item & $\begin{array}{l}\text { Total } \\
\text { solids }\end{array}$ & Fat & $\begin{array}{l}\text { Total } \\
\text { protein }\end{array}$ & $\begin{array}{l}\text { True } \\
\text { protein }\end{array}$ & CN & $\begin{array}{l}\text { Whey } \\
\text { protein }\end{array}$ & NPN & $\begin{array}{l}\text { Specific } \\
\text { gravity }\end{array}$ \\
\hline IgG & $0.85^{* * *}$ & 0.44 & $0.91^{* * *}$ & $0.91^{* * *}$ & $0.51^{*}$ & $0.92^{* * *}$ & 0.38 & $0.88^{* * * *}$ \\
Total solids & & $0.76^{* * *}$ & $0.93^{* * *}$ & $0.93^{* * *}$ & $0.74^{* * *}$ & $0.86^{* * *}$ & 0.45 & $0.85^{* * * *}$ \\
Fat & & & 0.48 & 0.47 & $0.62^{* *}$ & 0.37 & 0.39 & 0.32 \\
Total protein & & & & $0.99^{* * *}$ & $0.64^{* *}$ & $0.97^{* * *}$ & 0.43 & $0.96^{* * * *}$ \\
True protein & & & & & $0.63^{* *}$ & $0.97^{* * *}$ & 0.40 & $0.95^{* * *}$ \\
CN & & & & & 0.45 & $0.55^{*}$ & $0.57^{*}$ \\
Whey protein & & & & & & & 0.30 & $0.95^{* * *}$ \\
NPN & & & & & & & & 0.31 \\
\hline
\end{tabular}

${ }^{*} P<0.05 ; * * P<0.01 ; * * * P<0.001$.

and when milk secretion is maintained, the selective transfer decreases (Guy et al., 1994). Therefore, continuous milking during pregnancy of the D0 goats in our study maintained the activity of mammary epithelial cells but prevented the accumulation of IgG in the colostrum.

The IgG concentration in the colostrum of D0 goats $(5.6 \mathrm{mg} / \mathrm{mL})$ was greater than that reported by Levieux et al. (2002) in normal goat milk (0.20 to $2.21 \mathrm{mg} / \mathrm{mL}$ ). Nevertheless, this concentration seems to be insufficient to achieve the recommended serum concentration of IgG in newborn kids ( $>12 \mathrm{mg} / \mathrm{mL}$; O'Brien and Sherman, 1993). In addition, a positive correlation $(r=0.86)$ was detected between concentrations of IgG in the colostrum and in the serum of newborn kids (Argüello et al., 2004). When there is no dry period, a very large amount of colostrum must be fed to supply kids with a sufficient mass of IgG. However, large amounts of colostrum containing reduced concentrations of IgG would not be absorbed adequately (Stott and Fellah, 1983).

Concentrations of IgG did not vary between the D27 and D56 goats (Table 1), and ranged from 23.5 to 64.0 $\mathrm{mg} / \mathrm{mL}$ (overall mean $=39.6 \mathrm{mg} / \mathrm{mL}$ ). In accordance with our results, the immunologic quality of colostrum did not differ between dairy cows dried off for 30 or 70 d (Gulay et al., 2005).

Casein constituted 28.2, 28.1, and $63.1 \%$ of total protein in the colostrum of D56, D27, and D0 goats, respectively. The colostrum of $\mathrm{D} 0$ goats was close to normal goat milk in the Murciano-Granadina breed, where CN represents $75 \%$ of total milk protein. Whey protein, most of which was Ig, constituted over two-thirds of total protein in the colostrum from D56 and D27 goats and was greater $(P<0.01)$ than in colostrum from D0 goats (Table 1).

To our knowledge, correlations among IgG concentrations, SG, and other components of colostrum have not been reported previously in dairy goats (Table 2). Excluding values for the D0 goats, the concentrations of IgG correlated positively $(\mathrm{r}=0.88 ; P<0.001)$ with $\mathrm{SG}$, which were similar to the correlation of 0.84 reported by Fleenor and Stott (1980) in dairy cows but greater than the correlation of 0.53 reported by Morin et al. $(2001)$ in cows. Colostral SG were correlated $(P<0.001)$ with concentrations of protein $(\mathrm{r}=0.96)$, whey protein $(\mathrm{r}=0.95)$, and $\operatorname{IgG}(\mathrm{r}=0.88)$.

\section{Milk Yield}

Milk yield for lactations that preceded the dry period and those that followed the dry-period treatments are shown in Figure 1 and Table 3.

Preceding Lactation. Goats that tolerated continuous milking throughout pregnancy were not the best milk producers during the first 29 wk of pretreatment lactation $(2.25,2.12$, and $1.98 \mathrm{~L} / \mathrm{d}$ for D56, D27, and D0 goats, respectively). However, the D0 goats produced more $(P<0.01)$ milk than the D27 goats during wk 43 and 44 of lactation. Persistency of lactation was similar among groups before pregnancy but decreased as pregnancy advanced, with $\mathrm{D} 0$ goats having the greatest persistency during the third and fourth month of pregnancy (Table 3).

During the last 3 wk of gestation, milk yield increased for D0 goats (Figure 1). Circulating prolactin in dairy goats remained low up to d 120 of pregnancy and increased during the last part of pregnancy (Kornalijnslijper et al., 1997). Similarly, an increase in milk yield during the days preceding calving was observed in dairy cows (Wheelock et al., 1965), although Remond et al. (1992) did not detect such an increase.

Subsequent Lactation. Without a dry period, D0 goats produced $16 \%$ less $(P<0.01)$ milk during the subsequent lactation than during the previous lactation. Moreover, the milk yield of $\mathrm{D} 0$ goats during the subsequent lactation was reduced $(P<0.05)$ by 21 and $29 \%$ compared with the yields of D56 and D27 goats, respectively (Figure 1 and Table 3). On the other hand, D27 and D56 goats in the subsequent lactation produced $15 \%(P<0.01)$ and $4 \%(P=0.122)$, respectively, more milk than during the equivalent period of the 


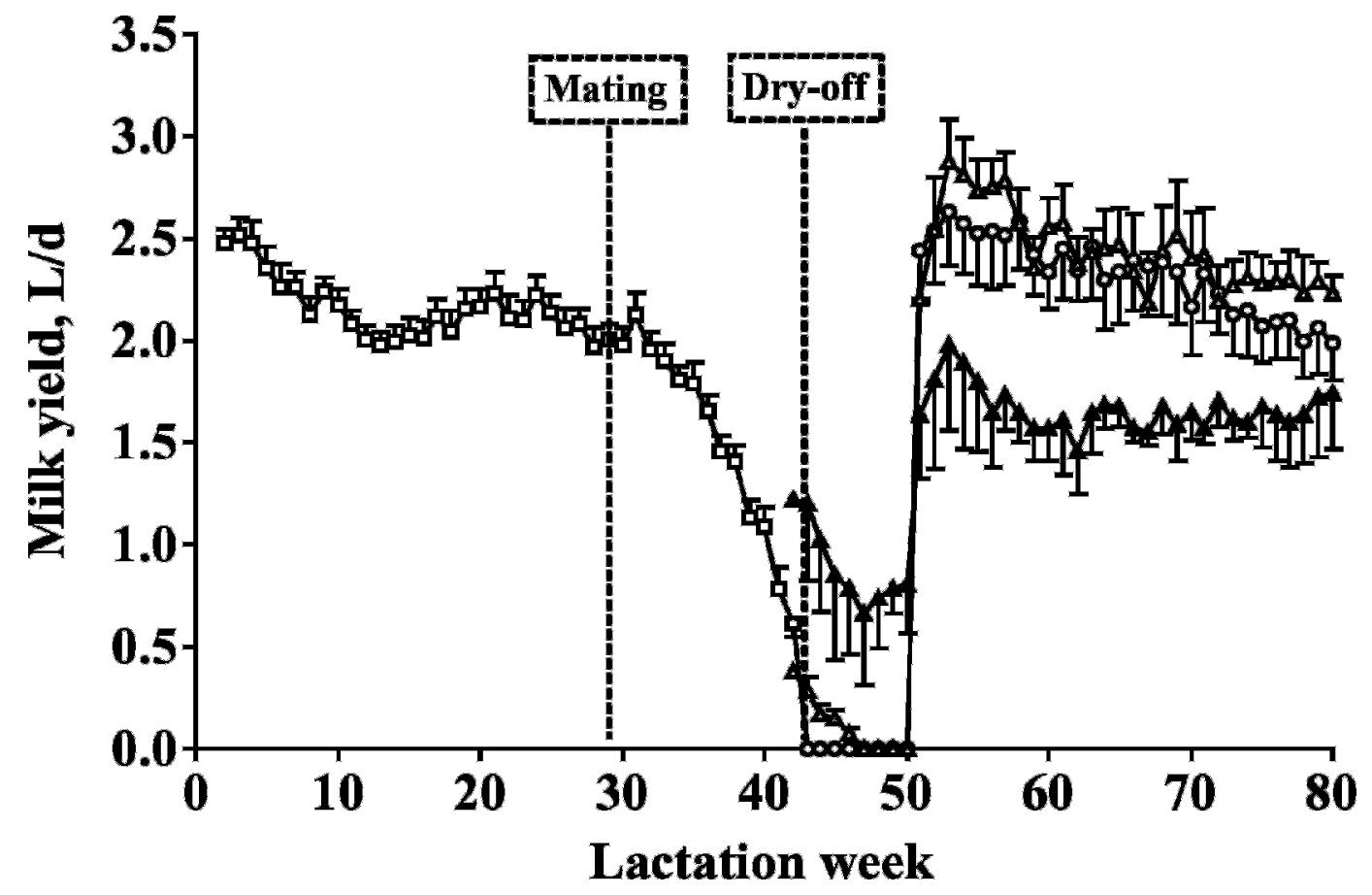

Figure 1. Milk yield of dairy goats during the pretreatment period ( $\square$; n = 17). At wk 42 of lactation, goats were allocated into 2 treatments: a dry period of $56 \mathrm{~d}(\mathrm{O} ; \mathrm{n}=9)$ or no dry period $(\mathrm{n}=8)$. At wk 47 of lactation, 5 of the 8 goats assigned to have no dry period dried off spontaneously at $27 \mathrm{~d}(\triangle ; \mathrm{n}=5)$ before parturition, and the remainder were milked continuously until parturition $(\boldsymbol{\Delta} ; \mathrm{n}=3)$.

Table 3. Effect of dry-period duration on milk yield and milk persistency in dairy goats

\begin{tabular}{|c|c|c|c|}
\hline \multirow[b]{2}{*}{ Item } & \multicolumn{3}{|c|}{ Dry-period duration ${ }^{1}$} \\
\hline & D56 $(\mathrm{n}=9)$ & $\mathrm{D} 27(\mathrm{n}=5)$ & $\mathrm{D} 0(\mathrm{n}=3)$ \\
\hline Parity number & $2.75 \pm 0.41$ & $3.00 \pm 0.63$ & $2.67 \pm 0.67$ \\
\hline \multicolumn{4}{|l|}{ Preceding lactation } \\
\hline \multicolumn{4}{|l|}{ Milk yield, L/d } \\
\hline Wk 2 to wk 29 & $2.25 \pm 0.10$ & $2.12 \pm 0.13$ & $1.98 \pm 0.16$ \\
\hline Wk 30 to wk 42 & $1.50 \pm 0.11$ & $1.46 \pm 0.13$ & $1.65 \pm 0.16$ \\
\hline Wk 43 to wk 46 & - & $0.15^{\mathrm{b}} \pm 0.10$ & $0.96^{\mathrm{a}} \pm 0.14$ \\
\hline Wk 47 to wk 50 & - & - & $0.75 \pm 0.10$ \\
\hline \multicolumn{4}{|l|}{ Milk persistency, \% } \\
\hline Before pregnancy ${ }^{2}$ & $67.6 \pm 2.3$ & $64.2 \pm 2.9$ & $69.7 \pm 3.8$ \\
\hline Mo 3 of pregnancy ${ }^{3}$ & $26.0^{\mathrm{b}} \pm 2.7$ & $27.6^{\mathrm{b}} \pm 3.5$ & $45.3^{\mathrm{a}} \pm 4.5$ \\
\hline Mo 4 of pregnancy ${ }^{4}$ & - & $4.8^{\mathrm{b}} \pm 3.6$ & $34.0^{\mathrm{a}} \pm 6.6$ \\
\hline \multicolumn{4}{|l|}{ Subsequent lactation } \\
\hline \multicolumn{4}{|l|}{ Milk yield, L/d } \\
\hline Wk 2 to wk 20 & $2.35^{\mathrm{a}} \pm 0.12$ & $2.60^{\mathrm{a}} \pm 0.16$ & $1.79^{b} \pm 0.20$ \\
\hline Wk 21 to wk 30 & $2.05^{\mathrm{ab}} \pm 0.08$ & $2.32^{\mathrm{a}} \pm 0.10$ & $1.76^{\mathrm{b}} \pm 0.12$ \\
\hline Wk 2 to wk 30 & $2.24^{\mathrm{a}} \pm 0.10$ & $2.51^{\mathrm{a}} \pm 0.13$ & $1.78^{\mathrm{b}} \pm 0.16$ \\
\hline Milk persistency ${ }^{5} \%$ & $65.1 \pm 4.6$ & $66.5 \pm 5.8$ & $75.8 \pm 7.5$ \\
\hline
\end{tabular}

${ }^{\mathrm{a}, \mathrm{b}}$ Means within a row having different superscript letters differ $(P<0.05)$.

${ }^{1}$ Dried off for $56 \mathrm{~d}$ (D56), dried off spontaneously for $27 \mathrm{~d}$ (D27), or without dry-off (D0).

${ }^{2}$ Milk yield during wk 26 to 29:milk yield during wk 2 to 6 .

${ }^{3}$ Milk yield during wk 39 to 42 :milk yield during wk 2 to 6 .

${ }^{4}$ Milk yield during wk 43 to 46 :milk yield during wk 2 to 6 .

${ }^{5}$ Milk yield during wk 27 to 30:milk yield during wk 2 to 6 . 


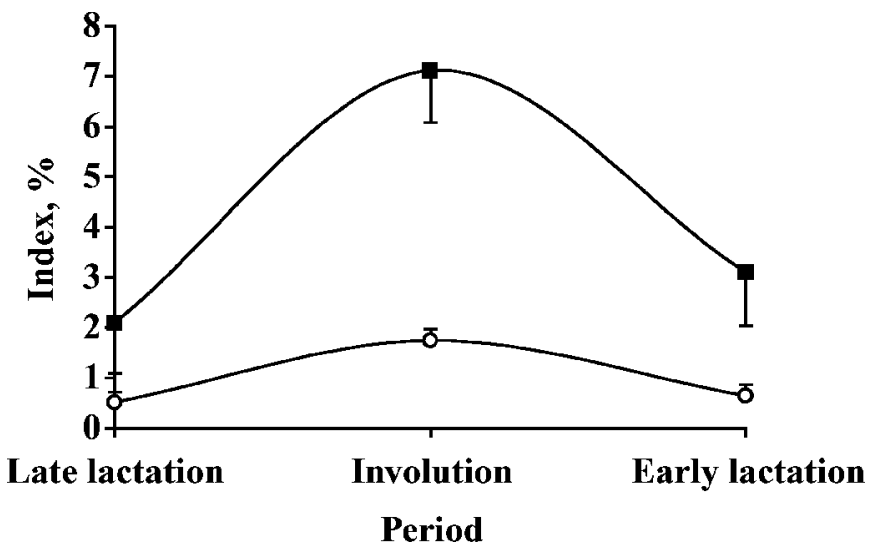

Figure 2. Apoptosis $(\bigcirc)$ and proliferation $(\square)$ indices in dairy goats milked for $300 \mathrm{~d}$ and dried off for $56 \mathrm{~d}$ before kidding $(\mathrm{n}=3)$. Biopsies were collected during late lactation (284 DIM), involution ( $7 \mathrm{~d}$ after drying off), and early lactation (48 DIM in the subsequent lactation).

previous lactation. In dairy cows, omitting the dry period also reduced milk production during the subsequent lactation by 15 to $40 \%$ (Swanson, 1965; Remond et al., 1992).

Using the half-udder design, Fowler et al. (1991) reported that a dry period between lactations was not necessary in Saanen dairy goats. In their study, halfudders were dried off 2 wk before mating (dry period lasted $23 \mathrm{wk}$ ), which is unusual and is 3 times the duration of the dry period in our study. In addition, when one half-udder was dried off, the activity and number of mammary cells increased in the lactating half within the same udder (Capuco and Akers, 1990), and involution was partially inhibited in the nonlactating half (Akers and Keys, 1985). In our study, both udder halves were dried off for a shorter period when goats were in late lactation and advanced pregnancy, which might explain the discrepancy between our results and those reported by Fowler et al. (1991).

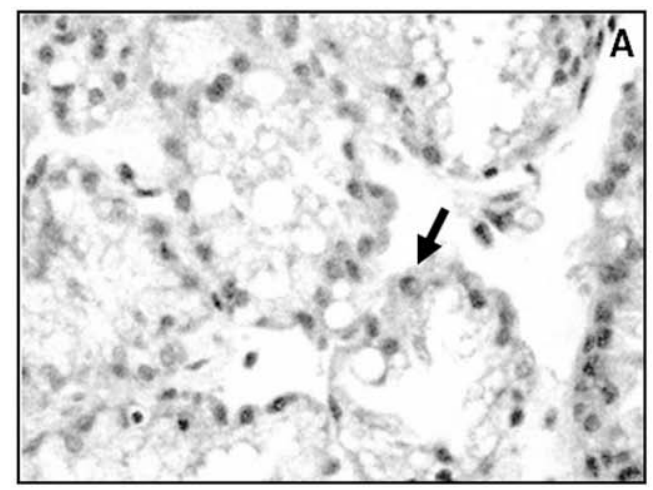

Milk persistency was numerically greater $(P=0.25)$ in D0 than in D56 and D27 goats (Table 3). When comparing D56 and D0 goats, milk yield was $24 \%$ less ( $P$ $<0.05)$ in D0 goats during the first 20 wk of lactation and $14 \%$ less $(P=0.097)$ in wk 21 to 30 of lactation (Figure 1 and Table 3). Similarly, milk yield from cows with no dry period (Remond et al., 1997) or with a 30$\mathrm{d}$ dry period (Bachman, 2002) was more persistent than that in cows with a conventional 60-d dry period.

No differences in milk yield were detected between D56 and D27 goats, indicating that shorter dry periods (i.e., $27 \mathrm{~d}$ ) are sufficient for mammary involution in goats. Consequently, no negative effects were expected when goats spontaneously dried off or were dried off intentionally 1 mo before kidding. Capuco et al. (1997) showed that mammary growth in cows was initiated within the first $25 \mathrm{~d}$ of a 60-d dry period. Moreover, cows with a 30-d dry period produced amounts of milk similar to cows with a 60-d dry period (Bachman, 2002).

\section{Mammary Cell Turnover}

Indices of apoptosis and proliferation in D56 goats at $284 \mathrm{DIM}$ of the preceding lactation, $7 \mathrm{~d}$ after drying off, and 48 DIM of the subsequent lactation are shown in Figure 2. Cellular indices of apoptosis $(0.61 \%)$ and proliferation $(2.52 \%)$ did not vary between mammary biopsies on d 284 and 48 of the preceding and subsequent lactations, respectively. These apoptosis values are in the range ( 0.2 to $3.0 \%$ ) reported in lactating cows (Capuco et al., 2001; Norgaard et al., 2005) and lactating goats ( $\mathrm{Li}$ et al., 1999). Similar to our proliferation values, cells expressing PCNA accounted for 0.17 to $2.99 \%$ of mammary cells during lactation in dairy cows (Norgaard et al., 2005). In our results, cell proliferation exceeded cell death, which suggests that the mammary gland grows throughout lactation rather than regressing. The TUNEL test detects the proportion of cells

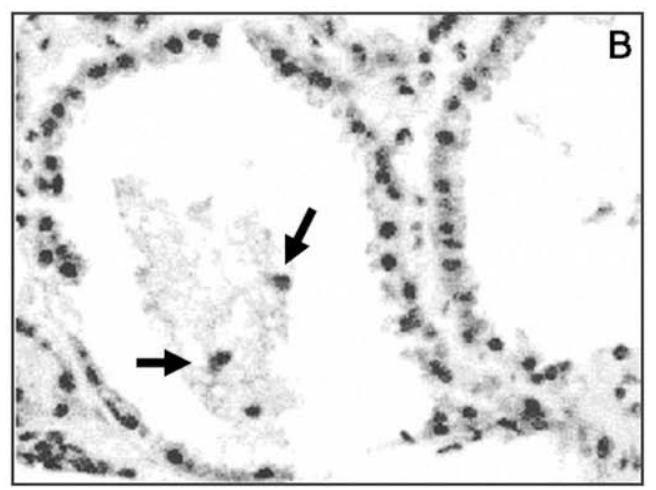

Figure 3. Identification of apoptotic cells in the mammary gland of dairy goats at 48 DIM of the posttreatment lactation. Apoptotic cells (arrows) were mainly localized in the alveolar epithelial cells (A) and some were in the alveolar lumen (B). 
Table 4. Effect of preceding dry-period duration on the number of epithelial cells per alveolus and indices of apoptosis and proliferation in the mammary gland of dairy goats at 48 DIM

\begin{tabular}{lccc}
\hline & \multicolumn{3}{c}{ Dry-period duration ${ }^{1}$} \\
\cline { 2 - 4 } Item & $\mathrm{D} 56(\mathrm{n}=3)$ & $\mathrm{D} 27(\mathrm{n}=3)$ & $\mathrm{D} 0(\mathrm{n}=3)$ \\
\hline Milk yield, L/d & $2.43^{\mathrm{a}} \pm 0.23$ & $2.74^{\mathrm{a}} \pm 0.19$ & $1.85^{\mathrm{b}} \pm 0.25$ \\
Cell number per alveolus & $38.6 \pm 7.1$ & $36.3 \pm 7.0$ & $24.1 \pm 5.0$ \\
Apoptotic cells, \% & $0.71 \pm 0.28$ & $0.68 \pm 0.28$ & $0.65 \pm 0.23$ \\
Proliferating cells, \% & $2.95 \pm 1.04$ & $1.37 \pm 1.04$ & $2.48 \pm 0.85$ \\
\hline${ }^{\mathrm{a}, \mathrm{b}}$ Means within a row having different superscript letters differ $(P<0.05)$. & \\
${ }^{1}$ Dried off for 56 d (D56), dried off spontaneously for 27 d (D27), or without dry-off (D0).
\end{tabular}

dying at a given moment before being phagocytosed by macrophages and adjacent alveolar cells, whereas PCNA indicates proliferating cells for approximately $24 \mathrm{~h}$ (Knight, 2000). In addition, milk may be a vehicle for eliminating mammary apoptotic cells as well as for phagocytosis. We observed some apoptotic cells in the alveolar lumen, and most of these cells were localized in the alveolar epithelium (Figure 3).

When comparing d 284 (late lactation) with d 7 after dry-off (involution) in D56 goats, an increase in mammary apoptosis $(0.51$ to $1.75 \% ; P<0.06)$ and proliferation $(2.09$ to $7.12 \% ; P<0.05)$ was observed (Figure 2 ). Similarly, Li et al. (1999) observed that the apoptosis index was less than $1 \%$ of cells in lactating tissues and increased at wk 1 (2 to $3 \%$ ) and $2(5 \%)$ after drying off nonpregnant goats.

The peak apoptosis probably occurred before $d 7$ of involution in our goats because they were in late pregnancy at drying off. Annen et al. (2003) detected the greatest incidence of apoptosis in pregnant cows at $d 2$ after drying off, and by $\mathrm{d} 8$ the number of apoptotic cells did not differ from those in lactating cows. Elevated apoptosis and proliferation indices during dry-off in our study indicate significant mammary cell turnover, as previously observed by Capuco et al. (1997) in dairy cows, in which proliferation of mammary epithelial cells in dry cows was greater than in cows without dry periods to replace senescent and damaged cells.

In the subsequent lactation (48 DIM), the numbers of cells per alveolus in D56 $(P=0.14)$ and D27 $(P=$ $0.19)$ goats were greater than those in D0 goats (Table 4 ), in accordance with milk yield values. In our results, milk yield correlated positively $(\mathrm{r}=0.81 ; P<0.05)$ with cell number per alveolus. No differences were detected between treatments in apoptosis or proliferation indices for D56, D27, and D0 goats, respectively (Table 4). Our results indicate that the length of the dry-off period did not affect mammary cell turnover in the following lactation.

However, the absence of a dry period might have negatively affected cell renewal before kidding in D0 goats, because these goats tended to have fewer $(P<$
0.20) numbers of cells per alveolus than D56 and D27 goats in the subsequent lactation (Table 4). Fitzgerald et al. (2004) observed that the proliferation of mammary epithelial cells in the glands of primiparous dairy cows dried off for $60 \mathrm{~d}$ was greater than in the glands without dry-off at $7 \mathrm{~d}$ before calving. These authors reported no differences after parturition in cell proliferation between glands with or without dry periods, suggesting that reduced cell proliferation before parturition caused milk yield losses in the subsequent lactation in glands without a dry period.

\section{CONCLUSIONS}

Omitting the dry period between lactations in Murciano-Granadina dairy goats had negative effects on milk production, probably because of impaired cellular replacement during dry-off, and is not recommended in practice. Milking during late pregnancy reduced kid birth weight and the immunological quality of the colostrum, which could negatively affect kid survival. Those goats that dried off spontaneously at $27 \mathrm{~d}$ before kidding were as productive as the goats dried off for $56 \mathrm{~d}$, and the colostrum quality was similar.

\section{ACKNOWLEDGMENTS}

This work is part of Centro de Investigación Científica y Tecnólogica research project (AGL2002-03472) and was supported by a research scholarship to A. A. K. Salama from the Agencia Española de Cooperación Internacional (AECI). The authors also are grateful to Ramón Costa and the team of the S1GCE (Servei de Granges i Camps Experimentals) of the Universitat Autónoma de Barcelona for the care of goats and to Nic Aldam for reviewing the manuscript.

\section{REFERENCES}

Akers, R. M., and J. E. Keys. 1985. Effect of suckling intensity on human growth hormone binding, biochemical composition and histological characteristics of ovine mammary glands. Domest. Anim. Endocrinol. 2:159-172. 
Annen, E. L., A. V. Capuco, P. C. Gentry, L. H. Baumgard, and R. J. Collier. 2003. Late gestation and advanced lactation at cessation of milking do not delay mammary epithelial apoptosis in dairy cattle. J. Dairy Sci. 86(Suppl. 1):117. (Abstr.)

Annen, E. L., R. J. Collier, M. A. McGuire, J. L. Vicini, J. M. Ballam, and M. J. Lormore. 2004. Effect of modified dry period lengths and bovine somatotropin on yield and composition of milk from dairy cows. J. Dairy Sci. 87:3746-3761.

Argüello, A., N. Castro, J. Capote, J. W. Tyler, and N. M. Holloway. 2004. Effect of colostrum administration practices on serum IgG in goat kids. Livest. Prod. Sci. 90:235-239.

Bachman, K. C. 2002. Milk production of dairy cows treated with estrogen at the onset of a short dry period. J. Dairy Sci. 85:797-803.

Brandon, M. R., and A. K. Lascelles. 1975. The effect of pre-partum milking on the transfer of immunoglobulin into mammary secretion of cows. Aust. J. Exp. Biol. Med. Sci. 53:197-204.

Capuco, A. V., and R. M. Akers. 1990. Thymidine incorporation by lactating mammary epithelium during compensatory mammary growth in beef cattle. J. Dairy Sci. 73:3094-3103.

Capuco, A. V., R. M. Akers, and J. J. Smith. 1997. Mammary growth in Holstein cows during the dry period: Quantification of nucleic acids and histology. J. Dairy Sci. 80:477-487.

Capuco, A. V., D. L. Wood, R. Baldwin, K. Mcleod, and M. J. Paape. 2001. Mammary cell number, proliferation, and apoptosis during a bovine lactation: Relation to milk production and effect of bST. J. Dairy Sci. 84:2177-2187.

Fitzgerald, A. C., E. L. Annen, P. C. Gentry, L. H. Baumgard, and R. J. Collier. 2004. Effects of continuous milking, bST and earlylactation milking frequency on mammogenesis, milk yield and composition in primiparous cows. J. Dairy Sci. 87(Suppl. 1):425. (Abstr.)

Fleenor, W. A., and G. H. Stott. 1980. Hydrometer test for estimation of immunoglobulin concentration in bovine colostrum. J. Dairy Sci. 63:973-977.

Fowler, P. A., C. H. Knight, and M. A. Foster. 1991. Omitting the dry period between lactations does not reduce subsequent milk production in goats. J. Dairy Res. 58:13-19.

Grummer, R. R., and R. R. Rastani. 2004. Why reevaluate length of dry period? J. Dairy Sci. 87(E. Suppl.):E77-E85.

Gulay, M. S., M. J. Hayen, H. H. Head, C. J. Wilcox, and K. C. Bachman. 2005. Milk production from Holstein half udders after concurrent thirty- and seventy-day dry periods. J. Dairy Sci. 88:3953-3962.

Guo, M. R., P. H. Dixon, Y. W. Park, J. A. Gilmore, and P. S. Kindstedt. 2001. Seasonal changes in the chemical composition of commingled goat milk. J. Dairy Sci. 84(E. Suppl.):E79-E83.

Guy, M. A., T. B. McFadden, D. C. Cockrell, and T. E. Besser. 1994. Regulation of colostrum formation in beef and dairy cows. J. Dairy Sci. 77:3002-3007.
Hale, S. A., A. V. Capuco, and R. A. Erdman. 2003. Milk yield and mammary growth effects due to increased milking frequency during early lactation. J. Dairy Sci. 86:2061-2071.

International Dairy Federation. 1993. Determination of milk nitrogen content. Standard 20B. International Dairy Federation, Brussels, Belgium.

Knight, C. H. 2000. The importance of cell division in udder development and lactation. Livest. Prod. Sci. 66:169-176.

Kornalijnslijper, J. E., B. Kemp, M. M. Bevers, H. A. Van Oord, and M. A. M. Taverne. 1997. Plasma prolactin, growth hormone and progesterone concentrations in pseudopregnant, hysterectomized and pregnant goats. Anim. Reprod. Sci. 49:169-178.

Levieux, D., F. Morgan, N. Geneix, I. Masle, and F. Bouvier. 2002 Caprine immunoglobulin G, $\beta$-lactoglobulin, $\alpha$-lactalbumin and serum albumin in colostrum and milk during early post partum period. J. Dairy Res. 69:391-399.

Lewis, M. J. 1987. Physical Properties of Foods and Food Processing Systems. VCH, Deerfield Beach, FL.

Li, P., P. S. Rudland, D. G. Fernig, L. M. B. Finch, and C. J. Wilde. 1999. Modulation of mammary development and programmed cell death by the frequency of milk removal in lactating goats. J. Physiol. 519:885-900.

Morin, D. E., P. D. Constable, F. P. Maunsell, and G. C. McCoy. 2001 Factors associated with colostral specific gravity in dairy cows. J. Dairy Sci. 84:937-943.

Norgaard, J., A. Sorensen, M. T. Sorensen, J. B. Andersen, and K. Sejrsen. 2005. Mammary cell turnover and enzyme activity in dairy cows: Effects of milking frequency and diet energy density. J. Dairy Sci. 88:975-982.

O'Brien, J. P., and D. M. Sherman. 1993. Serum immunoglobulin concentrations of newborn goat kids and subsequent kid survival through weaning. Small Rumin. Res. 11:71-77.

Remond, B., A. Ollier, and G. Miranda. 1992. Milking of cows in late pregnancy: Milk production during this period and during the succeeding lactation. J. Dairy Res. 59:233-241.

Remond, B., J. Rouel, N. Pinson, and S. Jabet. 1997. An attempt to omit the dry period over three consecutive lactations in dairy cows. Ann. Zootech. 46:399-408.

Sahlu, T., S. P. Hart, T. Le-Trong, Z. Jia, L. Dawson, T. Gipson, and T. H. Teh. 1995. Influence of prepartum protein and energy concentrations for dairy goats during pregnancy and early lactation. J. Dairy Sci. 78:378-387.

Stott, G. H., and A. Fellah. 1983. Colostral immunoglobulin absorption linearly related to concentration for calves. J. Dairy Sci. 66:1319-1328.

Swanson, E. W. 1965. Comparing continuous milking with sixty-day dry periods in successive lactations. J. Dairy Sci. 48:1205-1209.

Wheelock, J. V., J. A. F. Rook, and F. H. Dodd. 1965. The effect of milking throughout the whole pregnancy on the composition of cow's milk. J. Dairy Res. 32:249-254. 